\title{
Peranan Pergerakan Air Dalam-Tanah dalam Menurunkan Aliran Permukaan
}

\section{(The Role of Soil Water Movement in Reducing Surface Run Off)}

\author{
Enni Dwi Wahjunie*, Dwi Putro Tejo Baskoro, Suria Darma Tarigan
}

(Diterima Oktober 2020/Disetujui April 2021)

\begin{abstract}
ABSTRAK
Penyebab utama banjir dan erosi yang telah menciptakan lahan kritis di berbagai wilayah di Indonesia adalah aliran permukaan. Aliran permukaan terjadi apabila curah hujan telah melebihi kemampuan peresapan tanah. Kemampuan peresapan tanah dapat ditingkatkan melalui perbaikan pengelolaan tanah di setiap penggunaan lahan, yang sangat ditentukan oleh pergerakan air baik di permukaan maupun di dalam tanah. Penelitian ini bertujuan memprediksi aliran permukaan berdasar laju infiltrasi berbagai penggunaan lahan dan hujan di suatu wilayah. Serangkaian penelitian dilakukan di wilayah hulu dan tengah DAS Ciliwung. Sifat-sifat tanah, pergerakan air, dan curah hujan diamati di berbagai penggunaan lahan kering. Hasil penelitian menunjukkan bahwa besarnya laju infiltrasi konstan/kapasitas infiltrasi sangat ditentukan oleh sifat-sifat fisik tanah yang memengaruhi pergerakan air dalam-tanah. Waktu pencapaian laju infiltrasi konstan sangat ditentukan oleh kadar air awal infiltrasi dan derajat kejenuhan kadar air awal, serta sifat-sifat fisik tanah. Nilai laju infiltrasi konstan dan waktu pencapaiannya menentukan besarnya aliran permukaan yang terjadi.
\end{abstract}

Kata kunci: aliran permukaan, konduktivitas hidraulik, pengelolaan tanah, waktu pencapaian kapasitas infiltrasi

\begin{abstract}
The main cause of flooding and erosion that creates critical land in various regions in Indonesia is surface runoff. The surface runoff will occur if rainfall exceeds the capacity of soil water absorption (infiltration capacity). The soil management of each land use could improve the infiltration capacity. The water movement both on the surface and in the soil determines the water infiltration. This study predicts surface runoff based on the infiltration rate of various land uses and rainfall in the Ciliwung Watershed. A series of studies were performed in the upstream and middle areas of the watershed. Observations of soil properties, water movement, and rainfall were carried out in various dry land uses. The results showed that the soil's physical properties mostly determine the constant infiltration rate, which affected the water movement in the soil. The initial water content, the degree of saturation of the initial moisture content, and the soil's physical properties determine the time of constant infiltration rate. The value of constant rate infiltration and the time of its achievement determine the amount of surface runoff that occurs.
\end{abstract}

Keywords: hydraulic conductivity, run off, soil management, time achievement of infiltration capacity

\section{PENDAHULUAN}

Aliran permukaan sebagai penyebab erosi dan banjir, telah mempercepat peningkatan luas lahan kritis di beberapa wilayah daerah aliran sungai (DAS) di Indonesia. Walaupun reboisasi terus diupayakan, luas lahan kritis di Indonesia pada tahun 2018 masih 14,01 juta ha (Kemen LHK 2019). Kekritisan lahan di suatu DAS dapat menyebabkan banjir di musim hujan dan kekeringan di musim kemarau. Kondisi seperti ini dapat menimbulkan berbagai masalah baru, antara lain kekurangan ketersediaan air untuk irigasi sehingga produksi pertanian menurun.

Aliran permukaan dapat dikurangi dengan pengelolaan berbagai faktor yang memengaruhinya. Dari berbagai faktor yang memengaruhi aliran

Departemen IImu Tanah dan Sumberdaya Lahan, Fakultas Pertanian, Institut Pertanian Bogor, Kampus IPB Darmaga, Bogor 16680

* Penulis Korespondensi: Email: edwiwahjunie@yahoo.com permukaan, seperti curah hujan, kemiringan lereng, kondisi tanah, dan penutup tanah (vegetasi) (Liu et al. 2010; Wang et al. 2012; Zhang et al. 2017); kondisi tanah dan vegetasi penutup tanah merupakan faktor yang dapat dikelola untuk menurunkan aliran permukaan. Pengurangan aliran permukaan merupakan upaya pengelolaan hubungan curah hujan dan infiltrasi (Rodríguez-Blanco et al. 2012; Kumari et al. 2019). Kelebihan air hujan yang menjadi aliran permukaan dapat disebabkan oleh kelebihan jumlah hujan maupun kelebihan waktu terjadinya hujan (hujan berlangsung dalam waktu lama). Hujan yang berlangsung lama setelah saat tercapainya kapasitas infiltrasi berpotensi meningkatkan aliran permukaan. Alasan ini merupakan hal yang perlu diperhatikan dalam mengelola lahan agar tidak terjadi aliran permukaan. Hujan yang jatuh harus sebanyak-banyaknya diresapkan ke dalam tanah

Curah hujan yang ditentukan oleh jumlah, intensitas, distribusi, dan arah hujan merupakan hal yang tidak pasti. Namun, infiltrasi merupakan faktor yang dapat dikelola melalui perbaikan sifat-sifat tanah 
dengan mengelola tanah di setiap penggunaan lahan dalam jangka panjang. Peresapan air dapat ditingkatkan melalui peningkatan infiltrasi permukaan tanah maupun peningkatan laju pergerakan air (konduktivitas hidraulik) di dalam tanah (Li \& Shao 2006). Seperti yang telah dicermati oleh Bombino et al (2019), pemberian residu tanaman pada lahan telah dapat menurunkan aliran permukaan.

Penggunaan lahan di suatu bentang alam (landscape) DAS sangat beragam, tergantung pada wilayah apakah berada di hulu, tengah, atau hilir DAS. Pada umumnya, wilayah hulu dengan kelerengan yang lebih curam diperuntukkan bagi tanaman kayu-kayuan berakar dalam sebagai wilayah tangkapan air. Wilayah tengah dengan kelerengan relatif landai lebih diperuntukkan bagi tanaman pangan semusim, dan hilir sebagai wilayah urban. Distribusi penggunaan lahan di wilayah DAS tersebut mengikuti kaidah kemampuan lahan (Sys \& Debaveye, 1991) dan kesesuaian lahan (Prasetyo et al. 2001). Namun, hulu DAS yang merupakan wilayah tangkapan air biasanya memiliki suhu relatif rendah, sehingga banyak digunakan untuk pertanian tanaman pangan hortikultura dataran tinggi karena tanaman tersebut memerlukan suhu rendah.

Beberapa hasil penelitian menunjukkan bahwa perbedaan jenis penggunaan lahan telah berpengaruh pada laju peresapan air. Jenis penggunaan lahan berbeda dapat memperbaiki struktur tanah yang berbeda akibat perbedaan kandungan bahan organik tanah maupun perbedaan sifat perakarannya. Perbaikan struktur tanah oleh bahan organik dapat meningkatkan jumlah ruang pori, hantaran hidraulik jenuh, dan kapasitas infiltrasi (Ogban \& Utin 2015; Dionizio \& Costa, 2018; Zhang et al. 2018).

Seperti telah dikemukakan, peranan kemampuan peresapan air di berbagai penggunaan lahan akibat pengelolaannya dalam menurunkan aliran permukaan selain dipengaruhi oleh pergerakan air ke dalam tanah, juga ditentukan oleh sifat hujan baik jumlah maupun intensitasnya. Hubungan antara hujan dan pergerakan air tanah yang menentukan kemampuan peresapan air perlu dipelajari sehingga dapat diperkirakan besarnya aliran permukaan di setiap penggunaan lahan. Aliran permukaan pada skala DAS telah banyak diprediksi dengan menerapkan berbagai simulasi pada model. Namun, aliran permukaan pada jenis-jenis tutupan lahan (vegetasi) terkait perubahan sifat-sifat tanah pada pergerakan air sebagai hasil pengelolaan tanah perlu diprediksi. Berdasarkan ketersediaan data curah hujan jangka panjang di suatu wilayah maupun data pergerakan air dari berbagai tipe penggunaan lahan diharapkan besarnya aliran permukaan dapat diprediksi. Perbedaan aliran permukaan antarjenis penggunaan lahan tersebut diharapkan dapat menjadi masukan dalam pengelolaan lahan. Penelitian ini bertujuan memprediksi aliran permukaan berdasarkan data laju infiltrasi berbagai penggunaan lahan dan curah hujan di suatu wilayah. Sebagai salah satu upaya pengurangan banjir di musim hujan dan kekeringan di musim kemarau melalui pengurangan aliran permukaan, hubungan aliran permukaan dengan curah hujan dan peresapan air dikaji di wilayah hulu dan tengah DAS Ciliwung.

\section{METODE PENELITIAN}

\section{Lokasi Penelitian}

Penelitian dilaksanakan pada berbagai penggunaan lahan (tipe vegetasi) di Kabupaten Bogor, pada jenis tanah Inceptisol di DAS Mikro Cikardipa, Desa Sukagalih, Kecamatan Megamendung dan di Desa Bojong Koneng, Kecamatan Babakan Madang. Sifat tanah dianalisis di Laboratorium Konservasi Tanah dan Air, Departemen IImu Tanah dan Sumber Daya Lahan, Fakultas Pertanian, IPB University.

\section{Alat dan Bahan}

Alat-alat yang digunakan meliputi alat pengambilan contoh tanah di lapangan, permeameter untuk mengukur konduktivitas hidraulika, double ring infiltrometer untuk mengukur infiltrasi, dan alat-alat analisis sifat-sifat tanah di laboratorium. Sejumlah bahan kimia digunakan dalam analisis sifat-sifat tanah di laboratorium.

\section{Pelaksanaan Penelitian}

Tahapan penelitian meliputi penetapan lokasi di lapangan; pengukuran infiltrasi, konduktivitas hidraulik, dan pengambilan tanah di lapangan; penetapan sifatsifat tanah di laboratorium; serta pengolahan data.

Lokasi penelitian dipilih atas dasar lahan yang memiliki jenis tanah yang sama sehingga diharapkan sifat-sifat tanahnya berbeda akibat perbedaan penggunaan lahan (tipe vegetasi) dan pengelolaannya selama bertahun-tahun. Penggunaan lahan (tipe vegetasi) di Megamendung adalah bambu, kopi, dan tegalan; sedangkan di Babakan Madang adalah hutan sekunder, kebun campuran, dan tegalan.

Pada keenam penggunaan lahan tersebut diukur laju infiltrasi dan konduktivitas hidraulik; serta contoh tanah dicuplik untuk analisis sifat-sifat tanah. Laju infiltrasi diukur menggunakan metode falling head dengan alat double ring infiltrometer (Klute 1986). Infiltrasi diukur sampai mencapai laju konstan yang didahului dengan pengukuran kadar di sekitar double ring infiltrometer. Konduktivitas hidraulik diukur di kedalaman $0-20 \mathrm{~cm}$ dan $20-40 \mathrm{~cm}$ menggunakan permeameter (metode invers Auger Hole), didahului dengan pengukuran kadar air di sekitar permeameter. Konduktivitas hidraulik ditentukan hingga mencapai kecepatan tetap (konstan),

Contoh tanah untuk analisis sifat-sifat tanah diambil secara acak tiga ulangan pada setiap penggunaan lahan, terdiri atas contoh tanah utuh, contoh tanah agregat utuh, dan contoh tanah terganggu di kedalaman 0-20 cm dan 20-40 cm

Analisis sifat-sifat tanah di laboratorium meliputi tekstur, bobot jenis partikel, kadar C-organik, bobot isi, 
stabilitas agregat, dan retensi air tanah (kurva pF). Metode analisis sifat-sifat tanah adalah: tekstur tanah dengan metode pipet, kadar C-organik tanah dengan metode Walkley \& Black, bobot jenis partikel dengan metode piknometer; bobot isi dengan metode clod, stabilitas agregat dengan penetapan persentase agregat $(>2 \mathrm{~mm})$ stabil dengan pengayakan basah, retensi air dengan metode pressure plate, dan kadar air tanah secara gravimetrik.

\section{Analisis Data}

Laju infiltrasi konstan ditentukan dengan menetapkan data penurunan tinggi permukaan air di dalam silinder bagian dalam double ring infiltrometer. Kapasitas infiltrasi (laju infiltrasi minimum konstan) diduga dengan menggunakan persamaan Horton: $f=$ $f c+(f o-f c) e^{-k t} ; f=$ laju infiltrasi,$t=$ waktu (jam), $f o=$ laju infiltrasi awal $\left(\mathrm{cm} \mathrm{jam}^{-1}\right), f c=$ laju infiltrasi konstan $\left(\mathrm{cm} \mathrm{jam}{ }^{-1}\right), e=2.718$ (bilangan alam), dan $\mathrm{k}=$ konstanta yang menunjukkan penurunan laju infiltrasi (Viessman et al. 1977).

Waktu pencapaian kapasitas/laju infiltrasi konstan ditetapkan menggunakan analisis titik tetap dan kestabilan (Wahjunie et al. 2015) seperti pada Gambar 1. Waktu pencapaian laju infiltrasi konstan diduga melalui turunan pertama dari persamaan Horton. Persamaan turunan pertama dari model Horton tersebut mengarah ke titik tetap dan kestabilan, yaitu $f$ $=f c$ sehingga dapat ditentukan waktu pencapaian kapasitas infiltrasi konstannya. Perhitungan hantaran hidraulik jenuh menggunakan persamaan berikut:

$$
K=\frac{\left[\ln \left\{\mathrm{h} / \mathrm{r}+\left((\mathrm{h} / \mathrm{r})^{2}+1\right)^{0.5}\right\}-1\right] \mathrm{Q}}{2 \pi h^{2}}
$$

\section{Keterangan:}

$$
\begin{array}{ll}
K & =\text { Hantaran hidraulik }\left(\mathrm{cm} \mathrm{jam}^{-1}\right) \\
H & =\text { Tinggi kolom air }(\mathrm{cm}) \\
r & =\text { Jari-jari lubang }(\mathrm{cm})
\end{array}
$$

$$
\begin{array}{ll}
\pi & =3,14 \\
Q & =\text { Debit air }\left(\mathrm{cm}^{3} \mathrm{jam}^{-1}\right)
\end{array}
$$

Laju infiltrasi konstan, konduktivitas hidraulik jenuh, dan waktu pencapaian laju infiltrasi konstan dibandingkan secara deskriptif antarpenggunaan lahan. Pengurangan aliran permukaan pada setiap penggunaan lahan diperoleh dari perbandingan aliran permukaan antarpenggunaan lahan. Aliran permukaan hitung dengan membuat kurva hubungan simulasi intensitas hujan terhadap kurva laju infiltrasi tiap penggunaan lahan (tipe vegetasi); intensitas hujan disimulasikan dengan suatu nilai tertentu (Gambar 2). Data curah hujan yang digunakan untuk simulasi diperoleh dari pengamatan curah hujan harian penakar hujan otomatis di desa Sukagalih, Megamendung, ditambah data curah hujan harian di wilayah lokasi penelitian. Aliran permukaan ditentukan dari selisih intensitas hujan dengan laju infiltrasi maupun waktu ketercapaian laju infiltrasi konstan, dengan MS Excel.

\section{HASIL DAN PEMBAHASAN}

\section{Kondisi Umum Penggunaan Lahan \\ Lahan bambu, kopi, dan tegalan di Megamendung}

Lahan Bambu. Areal ini ditumbuhi bambu secara alami sejak tahun 1999. Tanaman bambu merupakan tanaman konservasi tanah dan air, karena mampu memperlambat aliran permukaan maupun serapan airnya sehingga dapat meningkatkan ketersediaan air dan penahan erosi dengan baik (Raka \& Wiswasta 2011). Serasah dan akar tanaman di bawah tanaman bambu dapat berfungsi sebagai penyaring air yang mengandung limbah melalui serabut-serabut akarnya.

Lahan Kopi. Tanaman kopi di lokasi penelitian berjenis arabika yang telah berumur 10 tahun. Namun, sejak tiga tahun terakhir lahan dan tanaman kopi

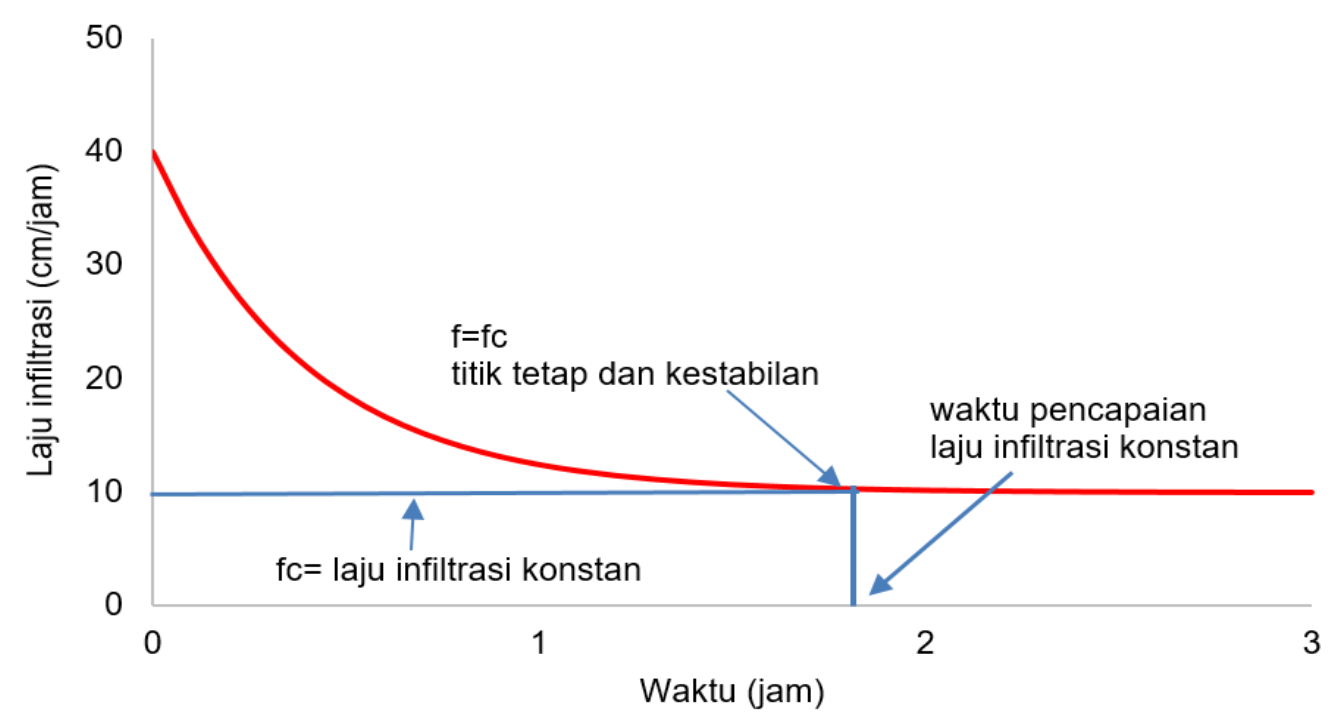

Gambar 1 Penetapan waktu pencapaian laju infiltrasi konstan. 


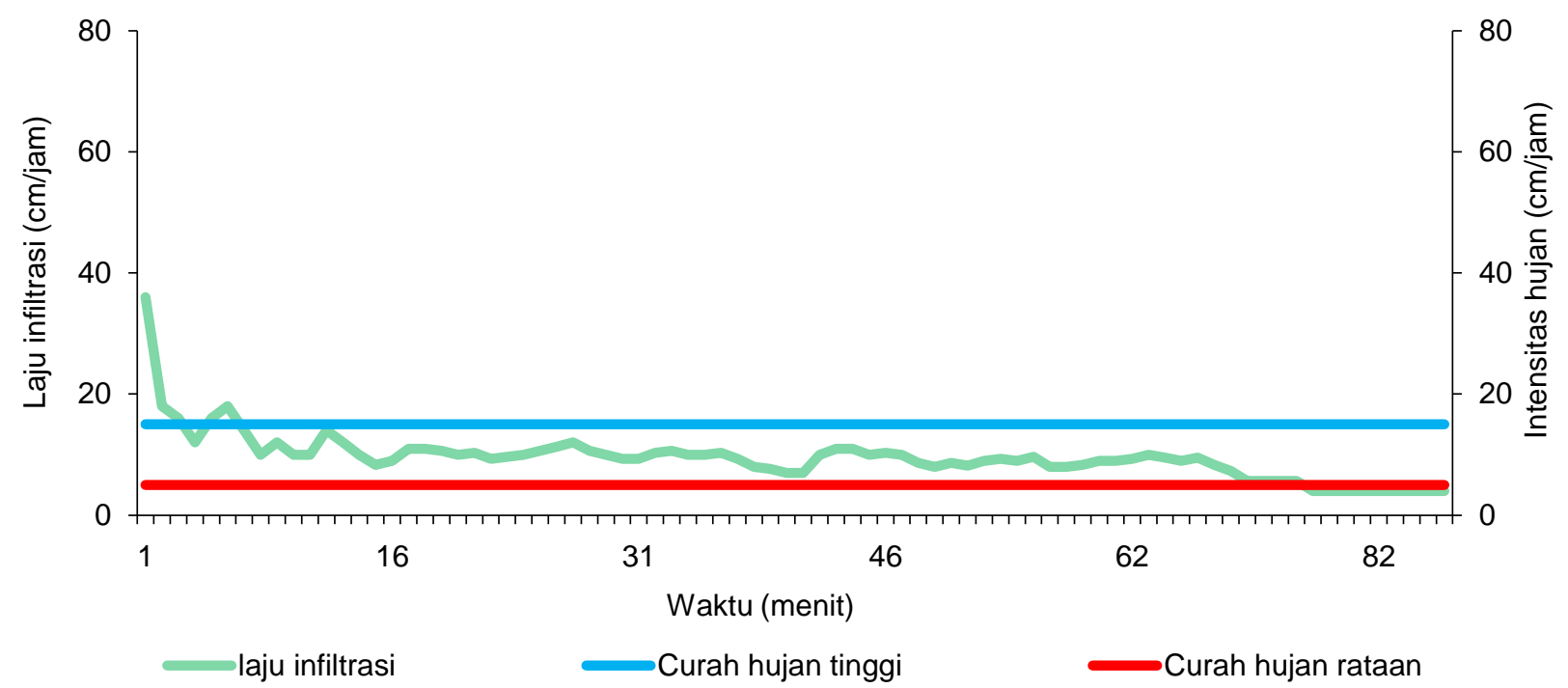

Gambar 2 Kurva hubungan laju infiltrasi dengan intensitas hujan pada curah hujan tinggi dan rataan.

terbengkalai dan tidak terawat. Kondisi ini menyebabkan rumput liar tumbuh di antara tanaman. Jarak tanam kopi yang sekitar 2 hingga 3 meter ditumbuhi rumput liar sehingga tanah lahan kopi menjadi cukup lembap. Tanah di lahan kopi ini mendapatkan sumbangan bahan organik yang cukup banyak dari serasah tanaman kopi maupun rumput liar yang tumbuh.

Tegalan. Tegalan di Megamendung merupakan area pertanian lahan kering, yang dikelola secara intensif sepanjang tahun, dengan tanaman yang diusahakan adalah tanaman sayuran semusim seperti kacang-kacangan, cabai, tomat, ubi jalar, dan daun bawang. Saat penelitian berlangsung, lahan tegalan sedang ditanami bawang daun umur 4 minggu setelah tanam (MST) yang ditumpangsarikan dengan tanaman kacang edamame. Penanaman sebagian besar searah lereng dengan tambahan tanaman pinggir berupa tanaman kayu-kayuan sebagai salah satu upaya rehabilitasi lahan. Pupuk kimia yang digunakan pada lahan tegalan adalah NPK dan TSP. Pengelolaan lahan tegalan sebagian besar menggunakan bahan organik sisa kotoran ternak dan sisa panen.

\section{Hutan Sekunder, Kebun Campuran, dan Tegalan di Babakan Madang}

Hutan Sekunder. Hutan sekunder ditumbuhi berbagai tanaman kayu-kayuan, yang didominasi oleh pohon jati, pinus, jabon, meranti, serta tumbuhan bawah sebagai penutup tanah seperti melastoma, rerumputan, dan tanaman liar lainnya. Serasah dari sisa-sisa tumbuhan menjadi sumber bahan organik tanah.

Kebun Campuran. Di area ini terdapat campuran tanaman semusim dan tanaman tahunan yang diusahakan sejak tahun 2003. Tanaman tahunan adalah jati sedangkan tanaman semusim adalah singkong dan pisang. Tanaman tahunan dibiarkan tumbuh tanpa ada perlakuan khusus sedangkan singkong diberi pupuk organik pada awal penanaman.
Saat pengamatan, singkong berumur 4-5 bulan. Tumbuhan penutup tanah adalah rerumputan. Tanah diolah saat awal tanam singkong, yaitu dengan pencangkulan dan pemberian pupuk organik berupa kotoran kambing.

Tegalan. Lahan tegalan ini sebelumnya merupakan lahan semak belukar dan sejak tahun 2004 terus menerus ditanami singkong. Pada saat penelitian, tanaman singkong telah berumur tiga bulan. Pengolahan tanah terakhir pada saat persiapan tanam. Permukaan tanah pada lahan ini tidak tertutupi oleh tajuk tanaman yang rapat. Pengelolaan pada lahan ini cukup intensif, meliputi pemberian pupuk organik kotoran kambing, pembersihan gulma, dan pencangkulan. Serasah pada lahan ini hanya berasal dari tanaman singkong.

\section{Sifat-sifat Tanah}

Proses masuknya air ke dalam tanah pada saat awal terjadi hujan dipengaruhi oleh sorpsitivitas dan transmisivitas air di permukaan tanah, diikuti oleh pergerakan air dalam-tanah (konduktivitas hidraulik dalam keadaan tak jenuh diikuti keadaan jenuh) (Ogban \& Utim 2015, Stolte 2003). Proses-proses tersebut sangat dipengaruhi oleh sifat-sifat tanah seperti tekstur, kadar bahan organik, bobot isi, distribusi pori, kontinuitas pori, dan stabilitas agregat dalam profil tanah. Sifat-sifat tanah tersebut ditampilkan pada Tabel 1.

Seluruh tanah di berbagai penggunaan lahan bertekstur klei, dengan kadar klei tanah di Babakan Madang lebih tinggi (56-61\% di kedalaman 0-20 cm; dan $64-71 \%$ di kedalaman $20-40 \mathrm{~cm}$ ) dibanding tanah di Megamendung (41-44\% di kedalaman 0-20 cm; dan 41-49\% di kedalaman 20-40 cm). Kadar bahan organik di Megamendung lebih tinggi daripada di Babakan Madang. Keadaan ini telah menciptakan bobot isi yang lebih rendah dan ruang pori drainase yang lebih tinggi. Nilai persentase agregat $>2 \mathrm{~mm}$ yang 
stabil tidak seiring dengan kadar bahan organik tanah. Proses agregasi tidak hanya ditentukan oleh bahan organik tanah. Tampaknya, jumlah klei yang lebih tinggi di tanah Babakan Madang telah memengaruhi proses agregasi tanah. Fungsi klei sebagai bahan penyemen dalam proses agregasi lebih kuat daripada bahan organik karena sifatnya lebih permanen (Kay 1990; Oades 1984). Pengaruh bahan organik dan klei secara bersama dalam proses agregasi terlihat pada ruang pori drainase. Ruang pori drainase yang tercipta di tanah-tanah Megamendung lebih banyak daripada ruang pori drainase di tanah-tanah Babakan Madang. Nilai ruang pori drainase yang tinggi merupakan potensi pergerakan air dalam-tanah yang lebih cepat. Pergerakan air dalam-tanah yang lebih cepat, selanjutnya dapat meningkatkan infiltrasi dan mengurangi aliran permukaan.

\section{Konduktivitas Hidraulik Jenuh dan Laju Infiltrasi Konstan}

Konduktivitas hidraulik jenuh tanah memengaruhi besarnya laju infiltrasi konstan, yang pada akhirnya memengaruhi aliran permukaan yang terjadi. Tanahtanah di berbagai penggunaan lahan di Megamendung memiliki konduktivitas hidraulik yang lebih tinggi dibanding tanah-tanah di Babakan Madang (Tabel 2). Pada kedalaman tanah $20-40 \mathrm{~cm}$ di tanah-tanah
Babakan Madang terjadi penurunan nilai konduktivitas hidraulik yang cukup nyata dibanding di kedalaman tanah $0-20 \mathrm{~cm}$. Perbedaan penggunaan lahan telah memengaruhi nilai konduktivitas hidraulik tanah akibat perbedaan struktur tanah yang tercipta (Ogban \& Utin 2015). Perbedaan tersebut terutama akibat pengaruh tipe vegetasi (Regues et al. 2017).

Laju infiltrasi konstan merupakan laju infiltrasi yang terjadi setelah waktu tertentu dalam suatu kejadian hujan. Tercapainya laju infiltrasi konstan ini akibat dari telah jenuhnya tanah sampai suatu kedalaman tertentu sehingga laju pergerakan air masuk ke dalam tanah dikendalikan oleh konduktivitas hidraulik jenuh. Namun, proses penjenuhan tanah sejak awal terjadi infiltrasi merupakan hal yang terjadi secara kompleks yang menyangkut beberapa proses dan sifat-sifat tanah dalam profil tanah. Selama waktu tertentu, zona kedalaman tanah yang dapat terbasahi bergantung pada kadar air awal, konduktivitas hidraulik tak jenuh yang nilainya terus berubah mengikuti perubahan nilai kadar air tanah, proses redistribusi dalam zona kedalaman tanah yang juga dipengaruhi oleh karakteristik retensi air tanah. Stolte (2003) menyatakan bahwa pengaruh penggunaan lahan pada laju infiltrasi dipengaruhi oleh sifat-sifat tanah yang terbentuk akibat pengelolaan lahan tersebut. Laju infiltrasi tanah dikendalikan oleh konduktivitas hidraulik

Tabel 1 Sifat-sifat tanah di berbagai penggunaan lahan

\begin{tabular}{|c|c|c|c|c|}
\hline $\begin{array}{c}\text { Lokasi/ } \\
\text { Penggunaan lahan }\end{array}$ & $\begin{array}{c}\text { Kadar bahan } \\
\text { organik (\%) }\end{array}$ & Bobot isi $\left(\mathrm{g} / \mathrm{cm}^{3}\right)$ & $\begin{array}{c}\text { Ruang pori } \\
\text { drainase } \\
\text { (\% volume) }\end{array}$ & $\begin{array}{c}\text { Agregat stabil } \\
(>2 \mathrm{~mm})(\%)\end{array}$ \\
\hline Megamendung: & \multicolumn{4}{|c|}{ Kedalaman tanah $0-20 \mathrm{~cm}$} \\
\hline Lahan Bambu & 5,17 & 0,74 & 23 & 14 \\
\hline Lahan Kopi & 6.89 & 0,79 & 29 & 12 \\
\hline Tegalan & 5,01 & 0,80 & 31 & 7 \\
\hline \multicolumn{5}{|c|}{ Kedalaman tanah $20-40 \mathrm{~cm}$} \\
\hline Lahan Bambu & 3,65 & 0,72 & 24 & 19 \\
\hline Lahan Kopi & 5,75 & 0,73 & 35 & 10 \\
\hline Tegalan & 3,16 & 0,77 & 33 & 24 \\
\hline Babakan Madang: & \multicolumn{4}{|c|}{ Kedalaman tanah 0-20 cm } \\
\hline Hutan Sekunder & 3,03 & 0,94 & 20 & 24 \\
\hline Kebun campuran & 2,61 & 1,10 & 15 & 17 \\
\hline Tegalan & 2,38 & 1,20 & 13 & 14 \\
\hline & \multicolumn{4}{|c|}{ Kedalaman tanah $20-40 \mathrm{~cm}$} \\
\hline Hutan Sekunder & 2,53 & 0,98 & 19 & 27 \\
\hline Kebun campuran & 1,93 & 1,15 & 13 & 24 \\
\hline Tegalan & 1,95 & 1,23 & 13 & 17 \\
\hline
\end{tabular}

Tabel 2 Konduktivitas hidraulik jenuh dan laju infiltrasi konstan di berbagai penggunaan lahan

\begin{tabular}{|c|c|c|c|}
\hline \multirow{3}{*}{$\begin{array}{l}\text { Lokasi/ } \\
\text { Penggunaan Lahan }\end{array}$} & \multirow{2}{*}{\multicolumn{2}{|c|}{$\frac{\text { Konduktivitas hidraulik jenuh }\left(\mathrm{cmjam}^{-1}\right)}{\text { Kedalaman Tanah }(\mathrm{cm})}$}} & \multirow{3}{*}{ Laju infiltrasi konstan $\left(\mathrm{cmjam}^{-1}\right)$} \\
\hline & & & \\
\hline & $0-20$ & $20-40$ & \\
\hline \multicolumn{4}{|l|}{ Megamendung } \\
\hline Bambu & 6,03 & 5,70 & 24,0 \\
\hline Kopi & 4,81 & 5,56 & 18,0 \\
\hline Tegalan & 4,23 & 4,28 & 17,0 \\
\hline \multicolumn{4}{|l|}{ Babakan Madang: } \\
\hline Hutan Sekunder & 5,93 & 0,13 & 13,0 \\
\hline Kebun campuran & 6,24 & 0,90 & 7.0 \\
\hline Tegalan & 2,46 & 0,65 & 4,0 \\
\hline
\end{tabular}


tak jenuh dan jenuh, karakteristik retensi air tanah, dan kadar air awal proses infiltrasi. Konduktivitas hidraulik tanah merupakan laju pergerakan air di dalam tanah. Semakin cepat laju pergerakan air di dalam tanah, semakin cepat peresapan air di permukaan tanah (infiltrasi), sehingga mengurangi air hujan yang mengalir di permukaan tanah (aliran permukaan).

\section{Waktu pencapaian laju infiltrasi konstan}

Selain laju infiltrasi konstan, waktu pencapaian laju infiltrasi konstan (Tabel 3) ikut menentukan besarnya aliran permukaan. Hujan yang terjadi pada waktu singkat, kemungkinan belum mencapai laju infiltrasi konstan. Hujan dengan intensitas tertentu yang berlangsung lama dapat mencapai laju infiltrasi konstan lebih cepat dan berpeluang terjadi aliran permukaan lebih cepat dibanding lahan yang lebih lama mencapai laju infiltrasi konstan.

Derajat kejenuhan kadar air awal tanah-tanah di Megamendung dan Babakan Madang relatif sama (Tabel 3), tetapi waktu pencapaian laju infiltrasi konstan berbeda-beda. Di lahan tegalan Megamendung, waktu pencapaian laju infiltrasi konstan adalah 97 menit, walaupun kadar air awal di atas kadar air kapasitas lapang dan derajat kejenuhan relatif sama dengan lahan bambu dan kopi. Di Babakan Madang, tanah di kebun campuran memerlukan 103 menit untuk mencapai laju infiltrasi konstan, walaupun kadar air awal sekitar kapasitas lapang dengan derajat kejenuhan hampir sama dengan lahan hutan sekunder dan tegalan.

Waktu pencapaian laju infiltrasi konstan sangat dipengaruhi oleh besarnya kadar air awal sebelum terjadinya hujan (infiltrasi), karakteristik retensi air tanah, dan sifat-sifat hidraulik lapisan tanah yang merupakan pengaruh bersama sifat-sifat lapisan tanah, karena waktu pencapaian laju infiltrasi konstan juga dipengaruhi oleh proses infiltrasi. Seperti telah dijelaskan, proses infiltrasi dipengaruhi oleh sifat hidraulik lapisan tanah, konduktivitas hidraulik tanah baik jenuh maupun tak jenuh, karakteristik retensi air tanah, dan kadar air awal sebelum proses infiltrasi.

Perbedaan nilai kadar air tanah awal terhadap kadar air pada kondisi kapasitas lapang maupun derajat kejenuhan kadar air awal, sangat menentukan besarnya laju infiltrasi awal. Kadar air awal menentukan konduktivitas hidraulik tak jenuh lapisan permukaan. Konduktivitas hidraulik tak jenuh ini menentukan proses redistribusi air ke lapisan tanah yang lebih bawah. Proses redistribusi air ke lapisan tanah bawah sangat dipengaruhi oleh karakteristik retensi air tanah. Pada awal infiltrasi, pergerakan air masuk ke dalam tanah dikendalikan oleh potensial matriks dan potensial gravitasi tanah. Derajat kejenuhan tanah menentukan besarnya potensial matriks tanah. Semakin tinggi derajat kejenuhan tanah, semakin rendah potensial matriks tanah. Semakin besar konduktivitas hidraulik tak jenuh, semakin cepat proses redistribusi dan juga semakin meningkat zona pembasahan lapisan tanah. Semakin dalam zona pembasahan tanah,semakin cepat tercapai laju infiltrasi yang konstan.

Pada saat awal terjadi hujan, kadar air dalam tanah masih rendah sehingga laju pergerakan air masuk ke dalam tanah lebih cepat. Seiring dengan kejadian hujan yang terus berlangsung, terjadi juga proses penjenuhan tanah. Pada saat tanah sudah mencapai jenuh, laju infiltrasi menjadi berkurang dan nilainya konstan. Laju infiltrasi konstan ini besarnya dikendalikan oleh laju pergerakan air di dalam tanah (konduktivitas hidraulik). Apabila tanah cepat jenuh, maka waktu pencapaian laju infiltrasi konstan juga cepat, sebaliknya jika lama mencapai jenuh, waktu pencapaiannya juga lama. Jadi, baik besarnya laju infiltrasi konstan maupun waktu pencapaiannya menentukan waktu tercapainya aliran permukaan dan besarnya aliran permukaan. Hasil-hasil penelitian yang telah ada, kebanyakan hanya memperhatikan nilai laju infiltrasi konstan, belum memperhatikan waktu pencapaian laju infiltrasi konstan. Sebagai gambaran di lapangan, apabila hujan terjadi selama berhari-hari sehingga tanah cenderung jenuh terus menerus, maka infiltrasi air masuk ke dalam tanah pada nilai konstan. Namun, jika laju pergerakan air di dalam tanah cukup cepat, maka laju infiltrasi konstan nilainya juga tinggi. Atau, jika terjadi hujan-hujan intensitas rendah dalam periode hujan, pergerakan air yang cepat di dalam tanah mendorong kondisi tanah tidak jenuh sehingga dapat meningkatkan laju infiltrasi kembali. Jadi, perbaikan tanah akibat pengelolaan dapat meningkatkan laju pergerakan air dalam tanah, meningkatkan laju infiltrasi konstan, dan pencapaian

Tabel 3 Waktu pencapaian laju infiltrasi konstan di berbagai penggunaan lahan

\begin{tabular}{|c|c|c|c|c|}
\hline Lokasi & \multirow{2}{*}{$\begin{array}{l}\text { Waktu pencapaian laju infiltrasi } \\
\text { konstan (menit) }\end{array}$} & \multicolumn{2}{|c|}{ Kadar air (\%) } & \multirow[b]{2}{*}{$\begin{array}{c}\text { Derajat kejenuhan } \\
(\%)\end{array}$} \\
\hline Penggunaan Lahan & & Awal & $\begin{array}{c}\text { Kapasitas } \\
\text { lapang }\end{array}$ & \\
\hline \multicolumn{5}{|l|}{ Megamendung: } \\
\hline Bambu & 85 & 35 & 46 & 69 \\
\hline Kopi & 53 & 52 & 38 & 67 \\
\hline Tegalan & 97 & 40 & 36 & 67 \\
\hline \multicolumn{5}{|l|}{ Babakan Madang: } \\
\hline Hutan Sekunder & 64 & 40 & 44 & 64 \\
\hline Kebun campuran & 103 & 40 & 43 & 69 \\
\hline Tegalan & 77 & 39 & 41 & 72 \\
\hline
\end{tabular}


waktu infiltrasi konstan. Secara keseluruhan, dampaknya adalah mengurangi aliran permukaan.

\section{Pengurangan Aliran Permukaan}

Pengurangan aliran permukaan dapat disimulasikan seperti pada Gambar 3 dan ditampilkan pada Tabel 4. Aliran permukaan di setiap penggunaan lahan diperhitungkan dari selisih laju infiltrasi tanah dengan intensitas hujan. Curah hujan harian tertinggi di lokasi penelitian pernah mencapai $103 \mathrm{~mm} / \mathrm{hari}$ yang terjadi pada waktu 40 menit. Nilai tersebut memiliki intensitas hujan sekitar $15 \mathrm{~cm} / \mathrm{jam}$. Curah hujan rataan pada musim hujan adalah sekitar $50 \mathrm{~mm} /$ hari. Nilai tersebut apabila terjadi pada kurun waktu satu jam, maka intensitas hujan adalah sekitar $5 \mathrm{~cm} / \mathrm{jam}$. Berdasarkan data-data curah hujan masa lalu tersebut dan dihubungkan dengan nilai laju infiltrasi yang terjadi di enam tipe penggunaan lahan di Megamendung dan Babakan Madang, maka dapat diperhitungkan penggunaan lahan mana yang lebih banyak mengurangi aliran permukaan.

Laju infiltrasi konstan tanah di seluruh lahan di Megamendung masih di atas intensitas hujan, baik pada curah hujan tinggi maupun curah hujan rataan. Akan tetapi, di seluruh tanah di Babakan Madang, laju infiltrasi konstan di bawah intensitas curah hujan tinggi,
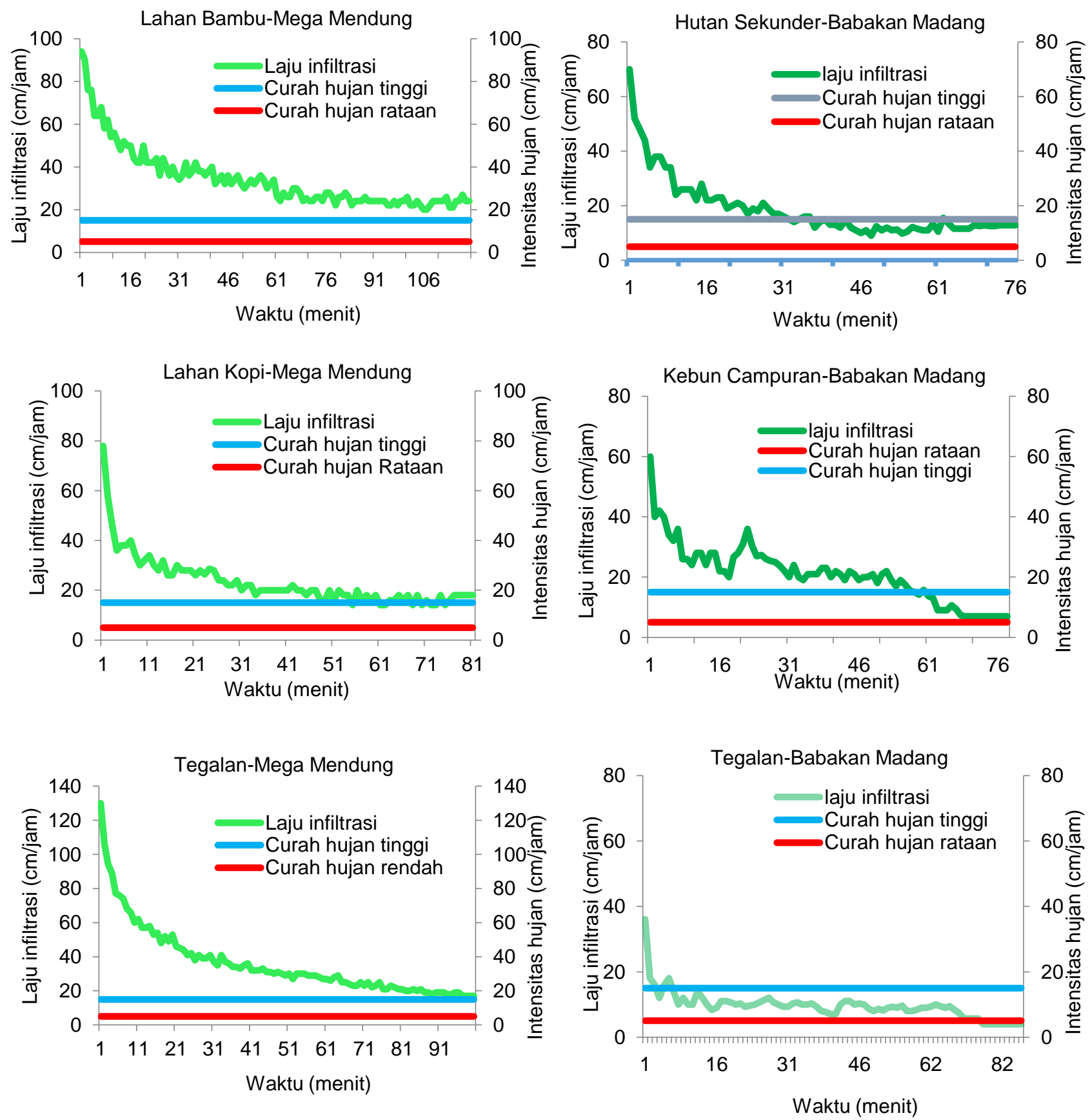

Gambar 3 Kurva hubungan laju infiltrasi dan intensitas curah hujan tinggi dan curah hujan rataan. 
Tabel 4 Aliran permukaan di berbagai penggunaan lahan, dengan simulasi hujan selama dua jam

\begin{tabular}{lcc}
\hline \multicolumn{1}{c}{ Lokasi } & \multicolumn{2}{c}{ Aliran permukaan $(\mathrm{mm})$, terjadi pada menit ke } \\
\cline { 2 - 3 } penggunaan lahan & Curah hujan rataan & Curah hujan tinggi \\
\hline Megamendung: & 0 & 0 \\
Bambu & 0 & 0 \\
Kopi & 0 & 0 \\
Tegalan & 0 & $32,11(50)$ \\
\hline Babakan Madang: & 0 & $37,25(80)$ \\
\hline Hutan sekunder & $7,17(77)$ & $62,19(4)$ \\
Kebun campuran & & \\
Tegalan &
\end{tabular}

bahkan di lahan tegalan, laju infiltrasi konstan di bawah intensitas curah hujan rataan, yang terjadi pada menit ke-77 (Gambar 3). Apabila terjadi curah hujan tinggi selama dua jam di hutan sekunder Babakan Madang, aliran permukaan dapat terjadi pada menit ke-50 dengan jumlah aliran permukaan sebesar $32,11 \mathrm{~mm}$. Pada kebun campuran Babakan Madang, jika terjadi curah hujan tinggi selama dua jam, aliran permukaan dapat terjadi mulai menit ke-80 dengan aliran permukaan total sebesar $37,25 \mathrm{~mm}$. Aliran permukaan di lahan tegalan Babakan Madang dapat terjadi baik pada curah hujan tinggi maupun pada curah hujan rataaan. Jika terjadi curah hujan tinggi selama dua jam, di lahan tegalan Babakan Madang dapat terjadi aliran permukaan sejak menit ke-4 dengan total aliran permukaan mencapai $62,19 \mathrm{~mm}$. Aliran permukaan akibat curah hujan rataan selama dua jam di lahan tegalan dapat menimbulkan aliran permukaan sejak menit ke-77 dengan total aliran permukaan 7,17 mm.

Simulasi yang ditampilkan pada Gambar 3 dan Tabel 4 menunjukkan bahwa pengelolaan tanah yang baik di berbagai penggunaan lahan dengan jenis vegetasi tertentu dapat memperbaiki sifat-sifat fisik tanah sehingga aliran permukaan menurun. Perbaikan sifat-sifat fisik tanah tersebut dapat meningkatkan pergerakan air di dalam tanah (konduktivitas hidraulik) maupun laju peresapan air (laju infiltrasi) tanah. Sebagian besar air hujan yang jatuh dapat diresapkan ke dalam tanah dengan cepat. Dengan demikian, jika tanah dikelola secara lebih baik, konservasi air maupun tanah dapat berhasil. Metode seperti yang ditampilkan pada Gambar 3 dan Tabel 4 tersebut dapat digunakan untuk memprediksi aliran permukaan setiap penggunaan lahan dengan berbagai tipe vegetasi di suatu wilayah secara lebih cepat. Data infiltrasi tanah dapat diperoleh dari pengamatan setiap penggunaan lahan. Data intensitas hujan dapat diprediksi berdasarkan data kejadian hujan masa lalu. Selanjutnya, prediksi aliran permukaan dengan metode ini dapat dimanfaatkan untuk upscaling pada skala DAS.

\section{KESIMPULAN}

Pengelolaan tanah pada lahan bambu, kopi, dan tegalan yang relatif baik dan telah dapat mempertahankan sifat-sifat tanah yang baik, dapat memengaruhi karakter pergerakan air sehingga dapat meningkatkan infiltrasi dan mengurangi aliran permukaan. Laju atau kapasitas infiltrasi konstan dan waktu pencapaiannya menentukan besarnya aliran permukaan yang terjadi. Pada lahan bambu, kopi, dan tegalan di wilayah hulu DAS Ciliwung tidak timbul aliran permukaan pada hujan tinggi maupun hujan rataan. Sebaliknya, hujan tinggi selama dua jam di lahan hutan sekunder, kebun campuran, dan tegalan di wilayah tengah DAS telah menyebabkan aliran permukaan masing-masing pada menit ke-50, ke-80, dan ke-4 masing-masing setinggi $32,11 \mathrm{~mm}, 37,25 \mathrm{~mm}$, dan $62,19 \mathrm{~mm}$. Aliran permukaan berdasarkan laju infiltrasi dan intensitas hujan suatu penggunaan lahan di suatu wilayah dapat diprediksi melalui pengamatan infiltrasi di setiap penggunaan lahan dan prediksi curah hujan berdasar data masa lalu.

\section{UCAPAN TERIMA KASIH}

Terima kasih saya ucapkan kepada Adhityo Guritno, Ogan Kaiwa, M. Lukman Fadly Nasution, dan M. Nurul Hadi atas bantuannya selama penelitian.

\section{DAFTAR PUSTAKA}

Bombino G, Denisi P, Gómez JA, Zema DA. 2019. Water Infifiltration and Surface Runoff in Steep Clayey Soils of Olive Groves under Different Management Practices. Water. 11(2): 240. https://doi.org/10.3390/w11020240

Dionizio EA, Costa MH. 2018. Influence of Land Use and Land Cover on Hydraulic and Physical Soil Properties at the Cerrado Agricultural Frontier. Agriculture. 21(1): $24 . \quad$ https://doi.org/ 10.3390/agriculture 9010024

Kay BD. 1990. Rates of changes of soil structure under different cropping systems. Advances in Soil Sciences. 12: 1-52. https://doi.org/10.1007/978-14612-3316-9_1

[KLHK] Kementerian Lingkungan Hidup dan Kehutanan. 2019. KLHK Tingkatkan Rehabilitasi 
Hutan dan Lahan Sepuluh kali lipat di 2019. Kemen LHK. Jakarta (ID).

Klute A. 1986. Methods Of Soil Analysis. American Society of Agronomy, Inc. Soil Science Society of America, Inc. Madison, Wisconsin Usa.

Kumari R, Mayoor M, Mahapatra S, Parhi PK, Singh HP. 2019. Estimation of Rainfall-Runoff Relationship and Correlation of Runoff with Infiltration Capacity and Temperature Over East Singhbhum District of Jharkhand. International Journal of Engineering and Advanced Technology. 9(2): 461-466.

https://doi.org/10.35940/ijeat.B3216.129219

Liu DD, Chen XH, Lian YQ. Impacts of climate change and human activities on surface runoff in the Dongjiang River basin of China. 2010. Hydrological Processes. 24 (11): 1487-1495. https:// doi.org/10.1002/hyp.7609

Li Y, Shao M. 2006. Effect of rainfall intensity on rainfall infiltration and redistribution in soil on loess slope land. www. Ncbi.nlm.nih.gov. 2 September 2019.

Oades JM. 1984. Soil organic matter and structure stability: mechanism and implications for management. Biological Processes and Soil Fertility: 319-337 in Developments in Plant and Soil Sciences vol 11. https://doi.org/10.1007/97894-009-6101-2_28

Ogban PI, Utin UE. 2015. Effect of land use on infiltration characteristics of sandstone-derived soils in Akwa Ibom State, Southeastern Nigeria. Journal of Applied Agricultural Research. 7: 141-149.

Prasetyo BH, Suhardjo H, Siswanto AB. 2001. Laporan Akhir Penyusunan Atlas Arahan Tata Ruang Pertanian Tingkat Nasional. Litbang Pertanian, Departemen Pertanian RI. P3HTA (Proyek Penelitian Penyelamatan Hutan, Tanah dan Air). 1985. Laporan Tahunan 1984/1985. Litbang Pertanian Departemen Pertanian RI.

Raka IDN, Wiswasta IGNA. 2011. Pelestarian tanaman bambu sebagai upaya rehabilitasi lahan dan konservasi tanah di daerah sekitar mata air pada lahan marginal di Bali Timur. Jurnal Pertanian Berbasis Keseimbangan Ekosistem. 1(1): 11-21.

Regues D, Badia D, Echeeverria MT, Gispert M, LanaRenault N, Leon J, Nadal-Romero E, Pardini G,
Serrano-Muela P. 2017. Analysing the effect of land use and vegetation cover on soil infiltration in three contrasting environments in Northeast Spain. Cuadernos de Investigación Geográfica Geographical Research Letters (CIG). 43(1): 141-169.

Rodríguez-Blanco ML, Taboada-Castro MMd Taboada-Castro MT. 2012. Rainfall-runoff response and event-based runoff coeffificients in a humid area (northwest Spain). Hydrological Sciences Journal. 57(3): 445-459. https://doi.org/10.1080/02626667.2012.666351

Stolte J. 2003. Effect of land use and infiltration behavior on Soil Conservation. Alterra Green World Research. Wageningen (ND).

Sys C, Debaveye J. 1991. Land evaluation, part 1: Principles in land evaluation and crop production calculation. In: General administration for development cooperation. Brussels, Belgium.

Viessman W, Knapp GL, Lewis, Harbaugh TE. 1977. Introduction toHydrology. New York (US): IEP-DunDonnelley Harper \& Row Publisher.

Wahjuni ED, Baskoro DPT, Purwakusuma W. 2016 Karakteristik Pergerakan dan ketersediaan air di Berbagai penggunaan lahan. Prosiding HITI 2015: Tanah untuk Kedaulatan Pertanian dan Keberlanjutan Kehidupan. Malang 28-31 Oktober 2015. Malang (ID).

Wang Y, Ding YJ, Ye BS, Liu FJ, Wang J, Wang J. 2012. Contributions of climate and human activities to changes in runoff of the Yellow and Yangtze rivers from 1950 to 2008. Science China Earth Sciences. 56: 1398-1412. https://doi.org/10.1007/ s11430-012-4505-1

Zhang GRY, Qian Z, Wang B. Zhao. 2014. Analysis of rainfall infiltration law in unsaturated soil slope. The Scientific World. Journal. 2014(7). https:// doi.org/10.1155/2014/567250

Zhang L, Srinivasan R, Bai ZK. 2017. Analysis of streamflflow response to climate variability and land use change in the Loess Plateau region of China. CATENA. 154: 1-11. https://doi.org/ 10.1016/j.catena.2017.02.012 